Justyna STECKO ${ }^{1}$

\title{
CSR 1.0 A CSR 2.0 PORÓWNANIE I ANALIZA POJEĆ́
}

\begin{abstract}
Artykuł podejmuje problematykę zarówno historycznej, jak i współczesnej możliwości zdefiniowania CSR. Celem opracowania jest przegląd definicji społecznej odpowiedzialności biznesu, które pojawiły się w XX wieku, oraz porównanie zebranego materiału z ujęciem, które zainicjowano w XXI wieku. Zanalizowano również opracowanie zaproponowane przez Wayne'a Vissera, który wprost mówi o potrzebie odrodzenia się CSR, ponieważ poprzednio zaproponowane ujęcia się nie sprawdziły.
\end{abstract}

Umart CSR! Niech żyje CSR! ${ }^{2}$

\section{WSTĘP}

Problematyka społecznej odpowiedzialności biznesu (CSR, corporate social responsibility) to pojęcie nie tylko bardzo popularne, ale także niezwykle ważne na płaszczyźnie społeczno-gospodarczej. Co prawda pierwsze próby ujęcia działalności biznesowej w ramy kodeksów i imperatywów wyznaczających zasady postępowania pojawiły się już w drugiej połowie XX wieku. Jednak próba skodyfikowania zasad dotyczących działań w biznesie w literaturze lat osiemdziesiątych czy nawet dziewięćdziesiątych wydaje się nie tyle pozbawiona błędów, ile mało dostosowana do potrzeb działań we współczesnych czasach. Zaangażowanie firm w społeczną odpowiedzialność przyniosło wiele pozytywnych skutków, jednak wydaje się, że do doskonałości pozostało jeszcze daleko. Próba podsumowania CSR - jego sukcesu czy też porażki - nie może obejść się bez odniesienia do płaszczyzny społeczno-środowiskowo-gospodarczej. Rozpocznę jednak od przeglądu definicji, które pojawiły się w opracowaniach i analizach w XX wieku.

\section{CSR - PRZEGLĄD DEFINICJI}

Samo pojęcie CSR, jak również jego zakres i próba definicji budzą liczne wątpliwości. Bywa ono rozumiane jako społeczna odpowiedzialność biznesu, ale także: „odpowiedzialność społeczna przedsiębiorstw” czy „odpowiedzialność korporacyjna”. Niekiedy pojawiają się określenia modyfikujące już to pojęcie: „korporacyjny zrównoważony rozwój” bądź „etyczna korporacja”. Każde jednak z nich akcentuje inny aspekt szeroko rozumianego CSR. Na potrzebę tego artykułu przyjęto najbardziej popularne thumaczenie pojęcia CSR: społeczna odpowiedzialność biznesu. Prekursorów społecznej odpowiedzialności można znaleźć w tekstach starożytnych filozofów, jednak pierwsze definicje, wskazujące na współczesne rozumienie tego zjawiska, pojawiły się dopiero w latach pięć-

${ }^{1}$ Dr Justyna Stecko, Zakład Nauk Humanistycznych, Wydział Zarządzania, Politechnika Rzeszowska

${ }^{2}$ W. Visser, CSR.2.0. The Evolution and Revolution of Corporate Social Responsibility [w] M. Pohl, N. Tolhurst, Responsible Business: How to Manage a CSR Strategy Successfully, Wiley, London 2010, rozdz. 21. 
dziesiątych XX wieku³ ${ }^{3}$ Przed 1950 rokiem można się spotkać ze zjawiskiem SR czy szeroko rozumianej odpowiedzialności społecznej. Jednak jedną z pierwszych definicji CSR sformułował Howard Bowen, wskazując na potrzebę realizacji przez przedsiębiorców również tych zadań, które są społecznie pożądane, między innymi określonych wartości. Tak określona płaszczyzna wykraczała poza płaszczyznę finansową i prawną, która do czasów współczesnych, nie straciła na znaczeniu. Kolejne powstające definicje i zmiany w ujęciu problematyki były warunkowane głównie dynamicznymi zmianami, które zaszły w ciagu kilku ostatnich dziesięcioleci. Od początku lat pięćdziesiątych aż do dzisiaj tworzone są kolejne próby stworzenia trafnej i aktualnej definicji społecznej odpowiedzialności. I tak jak dynamiczna jest rzeczywistość, tak specjaliści próbują odnaleźć klucz, w którym będzie można zamknąć definicję CSR. Od połowy XX wieku aż do jego końca panowała tendencja do coraz bardziej szczegółowych opracowań. W tabeli 1 dokonano próby przeglądu najważniejszych ujęć CSR.

Tabela 1. Przegląd definicji CSR sformułowanych w XX wieku

\begin{tabular}{|c|c|}
\hline \multicolumn{2}{|c|}{ SPOLECZNA ODPOWIEDZIALNOŚĆ BIZNESU } \\
\hline Bowen (1953) & $\begin{array}{l}\text { To zobowiązania przedsiębiorców do realizowania } \\
\text { takiej polityki, podejmowania takich decyzji i wy- } \\
\text { tyczania takich linii działania, które będą pożądane } \\
\text { na płaszczyźnie celów i wartości naszego społe- } \\
\text { czeństwa }\end{array}$ \\
\hline McGuire (1963) & $\begin{array}{l}\text { Idea odpowiedzialności społecznej zakłada, że } \\
\text { korporacja ma nie tylko obowiązki natury gospo- } \\
\text { darczej i prawnej, ale również pewne zobowiązania } \\
\text { wobec społeczeństwa, które wykraczają poza te } \\
\text { obowiązki }\end{array}$ \\
\hline Davis (1973) & $\begin{array}{l}\text { Uwzględnianie oraz reagowanie przez firme na } \\
\text { zagadnienia wykraczające poza wąskie gospodar- } \\
\text { cze, techniczne i prawne wymagania wobec } \\
\text { niej[...], aby osiągnąć korzyści społeczne oprócz } \\
\text { radycyjnych zysków ekonomicznych, do których } \\
\text { dąży firma }\end{array}$ \\
\hline Sethi (1975) & $\begin{array}{l}\text { CSR polega na podniesieniu zachowań korporacyj- } \\
\text { nych do poziomu, na którym odpowiadają one } \\
\text { dominującym społecznym normom, wartościom i } \\
\text { oczekiwaniom }\end{array}$ \\
\hline Davis i Blomstrom (1975) & $\begin{array}{l}\text { CSR to zobowiązanie kadry zarządzającej do po- } \\
\text { dejmowania działań mających na celu ochronę i } \\
\text { poprawę zarówno dobrobytu społeczeństwa, jak } \\
\text { interesu organizacji }\end{array}$ \\
\hline Frederick (1978) & $\begin{array}{l}\text { Społeczna reaktywność biznesu to zdolność korpo- } \\
\text { racji do reakcji na nacisk społeczny, dosłowny akt } \\
\text { reakcji; lub też do przyjęcia reaktywnej generalnie }\end{array}$ \\
\hline
\end{tabular}

\footnotetext{
${ }^{3}$ Krótka historia pojęcia CSR w: J. Stecko, Zaufanie a spoleczna odpowiedzialność biznesu, „Zeszyty Naukowe Politechniki Rzeszowskiej, Zarządzanie i Marketing” 2012/2.
} 


\begin{tabular}{|c|c|}
\hline & postawy wobec społeczeństwa \\
\hline Carroll (1979) & $\begin{array}{l}\text { Społeczna odpowiedzialność biznesu obejmuje } \\
\text { ekonomiczne, prawne, etyczne i uznaniowe ocze- } \\
\text { kiwania, jakie społeczeństwo ma wobec organizacji } \\
\text { w danym momencie (przedstawiona w formie pi- } \\
\text { ramidy w latach dziewięćdziesiątych }{ }^{4} \text { ) }\end{array}$ \\
\hline Wood (1991) & $\begin{array}{l}\text { Społeczna odpowiedzialność biznesu to przyjęta w } \\
\text { organizacji biznesowej konfiguracja zasad odpo- } \\
\text { wiedzialności społecznej, procesów reaktywności } \\
\text { społecznej oraz polityk, programów i widocznych } \\
\text { wyników powiązanych z relacjami społecznymi } \\
\text { firmy }\end{array}$ \\
\hline Brown i Dacin (1997) & $\begin{array}{l}\text { Społeczne spojrzenie na CSR odpowiada statusowi } \\
\text { firmy i działaniom w zakresie spełniania obowią- } \\
\text { ków wobec społeczeństwa }\end{array}$ \\
\hline McIntosh i in. (1998) & $\begin{array}{l}\text { Społecznie odpowiedzialny biznes dotyczy relacji } \\
\text { między spółkami i społeczeństwem - zarówno } \\
\text { społecznością lokalną, która otacza biznes oraz } \\
\text { której członkowie wchodzą w interakcje z pracow- } \\
\text { nikami firmy, jak również szerszą społecznością } \\
\text { obejmującą cały świat, która dotyka firm za po- } \\
\text { średnictwem ich produktów, łańcucha dostaw, sieci } \\
\text { dystrybutorów, reklam itd. }\end{array}$ \\
\hline McIntosh i Mohan (1999) & $\begin{array}{l}\text { Odpowiedzialny biznes polega na uwzględnianiu } \\
\text { kwestii społecznych i środowiskowych w głównej } \\
\text { działalności firmy }\end{array}$ \\
\hline $\begin{array}{l}\text { Maignan, Ferrell and Hult } \\
\text { (1999) }\end{array}$ & $\begin{array}{l}\text { Społecznie odpowiedzialny biznes oznacza to, w } \\
\text { jakim stopniu firma podejmuje ekonomiczne, } \\
\text { prawne, etyczne i uznaniowe zobowiązania nakła- } \\
\text { dane na nią przez strony w zaangażowane w jej } \\
\text { działalność }\end{array}$ \\
\hline
\end{tabular}

Źródło: opracowanie własne na podstawie zestawienia Valérie Swaen, Corporate social responsibility: do managers and consumers have the same conception of 'doing good'? Tekst prezentowany na 10. międzynarodowej konferencji Greening of Industry Network, https://gin.confex.com/gin/archives/2002/papers/010140Swaen.pdf (dostęp: 30 X 2012).

Przy ogromnym zainteresowaniu problemem CSR na przełomie XX i XXI wieku powstały kolejne opracowania i próby nowoczesnego ujęcia. Wydaje się jednak, że na potrzebę tego artykułu warto przytoczyć jedynie 3 najbardziej aktualne, a zarazem ważne definicje. Pierwsza z nich to Global Compact, inicjatywa zapoczątkowana przez Sekretarza Generalnego ONZ Kofi Annana. Zasady te - jedne z najbardziej znanych i chyba najczęściej cytowanych - pozostawiam jedynie w formie przypomnienia uporządkowane w tabeli $2 .$. 
Tabela 2. Zasady Global Compact

\begin{tabular}{|l|l|}
\hline \multicolumn{2}{|c|}{ GLOBAL COMPACT } \\
\hline PRAWA CZŁOWIEKA & $\begin{array}{l}\text { Popieranie i przestrzeganie praw człowieka przyję- } \\
\text { tych przez społeczność międzynarodową } \\
\text { Eliminacja wszelkich przypadków łamania praw } \\
\text { człowieka przez firmę }\end{array}$ \\
\hline STANDARDY PRACY & $\begin{array}{l}\text { Poszanowanie wolności zrzeszania się } \\
\text { Eliminacja wszelkich form pracy przymusowej } \\
\text { Zniesienie pracy dzieci } \\
\text { Efektywne przeciwdziałanie dyskryminacji w sferze } \\
\text { zatrudnienia }\end{array}$ \\
\hline ŚRODOWISKO NATURALNE & $\begin{array}{l}\text { Prewencyjne podejście do środowiska naturalnego } \\
\text { Podejmowanie inicjatyw majaccych na celu promo- } \\
\text { wanie postaw odpowiedzialności ekologicznej } \\
\text { Stosowanie i rozpowszechnianie przyjaznych śro- } \\
\text { dowisku technologii }\end{array}$ \\
\hline $\begin{array}{l}\text { PRZECIWDZIAŁANIE } \\
\text { RUPCJI }\end{array}$ & $\begin{array}{l}\text { Przeciwdziałanie korupcji we wszystkich formach, } \\
\text { w tym wymuszeniom i łapówkarstwu }\end{array}$ \\
\hline
\end{tabular}

Źródło: opracowanie własne na podstawie: http://www.globalcompact.org.pl/GlobalCompact/10-Zasad-GC (dostęp: 15 X 2012)

Kolejne z nowoczesnych ujęć to propozycja ISO 26000, wskazująca na „Odpowiedzialność organizacji za wpływ jej decyzji i działań (produkty, serwis, procesy) na społeczeństwo i środowisko" ". Jak widać, pojawiła się odwrotna niż w XX wieku tendencja, tym razem dąży się do rozszerzonej próby definiowania. Ostatnia z definicji, którą chciałam przytoczyć, to nie tylko najbardziej aktualne ujęcie, ale także najbardziej pojemne. Komisja Europejska zdefiniowała CSR jako „odpowiedzialność przedsiębiorstw za ich wpływ na społeczeństwo" 6 .

W tekście celowo pominięto rozróżnienie na (skądinąd ważny) podział na modele after profit i before profit obligation. Pierwszy z nich - odwołując się do najpopularniejszej piramidy CSR Carrolla - wskazuje wyłącznie na wybór pomiędzy ryzykowną decyzją a zyskiem w płaszczyźnie ekonomicznej, żądając jednocześnie odpowiedzialności przedsiębiorstw po osiagnięciu zysku. Paweł Polowczyk nazywa takie działania modelem „umiarkowanego przestępcy”" . Before profit obligation daje większą swobodę w wyborze środków, metod, a nawet celów, jednocześnie wskazując na odpowiedzialność, niezależnie od realnych zysków. Celem artykuły nie jest jednak wyczerpujący przegląd definicji, modeli i podziałów, a jedynie przygotowanie teoretyczne do porównania tradycyjnego ujęcia CSR z nowoczesnym, ciekawym i wydaje się, że ciagle zbyt mało popularnym w Polsce ujęciem Wayne’a Vissera. Zdaniem wspomnianego badacza jesteśmy świadkami

\footnotetext{
${ }^{5}$ http://www.odpowiedzialnafirma.pl/o-csr/iso-26000 (dostęp: 10 X 2012).

${ }^{6}$ Komunikat Komisji do Parlamentu Europejskiego, Rady, Europejskiego Komitetu Ekonomiczno-Społecznego i Komitetu Regionów oraz odnowiona strategia UE na lata 2011-2014 dotycząca społecznej odpowiedzialności przedsiębiorstw: http://eur-lex.europa.eu/LexUriServ/LexUriServ.do?uri=COM:2011:0681:FIN:PL:PDF (dostęp: 15 VIII 2012).

${ }^{7}$ P. Polowczyk, Odpowiedzialność biznesu i podmiotów gospodarczych: definicje, modele, typologia argumentacji, „Zarządzanie zmianami” 2012/1, s. 44.
} 
schyłku pojęcia CSR, mimo jego pozornego dynamicznego rozwoju. Możliwości - zdaniem Vissera - są dwie: albo nastąpi jego intensywne odrodzenie, albo nagła śmierć.

\section{CSR WEDLUG WAYNE'A VISSERA}

Wayne Visser w swoim ujęciu społecznej odpowiedzialności biznesu wyróżnia 5 kolejnych etapów w rozwoju CSR przedsiębiorstw. Są to:

- era chciwości,

- era filantropii,

- era marketingu,

- $\quad$ era zarządzania i wreszcie

- $\quad$ era odpowiedzialności ${ }^{8}$.

W pierwszym etapie działalności firma nastawiona jest jedynie na działania defensywne i maksymalizację zysku, a jedynie w sytuacjach kryzysowych podejmuje próbe naprawy. To czas, kiedy firma dba jedynie o bilans własnego konta bankowego. Kolejny etap to krok w stronę pozytywnego nastawienia do ludzi i w konsekwencji do działań charytatywnych i inicjatyw społecznych. Era trzecia to czas promocji, budowania pozytywnego wizerunku oraz próby wykorzystania CSR jako jednego z narzędzi działań marketingowych. Etap zarządzania to czas strategicznych działań firm związanych z realizacją zrównoważonego rozwoju. Na tym etapie kończy się również zdaniem Wayne’a Vissera tradycyjne ujęcie, czyli CSR 1.0, na rzecz CSR 2.0, które wskazuje na inne i zdecydowanie bardziej aktualne pojęcie odpowiedzialności. Dotychczasowe definicje wskazywały na choć często spektakularne, to jednak zbyt mało skuteczne działania firm. Często okazuje się, że działania prowadzone są głównie z powodu dbałości o wizerunek i po osiagnięciu zamierzonego efektu, są wygaszane.

\section{CSR 1.0 A CSR 2.0}

Co kryje się pod tym tajemniczym ujęciem CSR 2.0. Ujęcie to przede wszystkim budzi bezpośrednio skojarzenia z WEB 2.0. Nowa nazwa nie wiąże się jednak wyłącznie z użyciem nowych technologii i dużą popularnością mediów społecznościowych w komunikacji CSR.

Wayne Visser zwraca uwagę aż na pięć różnic między CSR 1.0 a CSR 2.0. Należą do nich:

- $\quad$ tworzenie więzi (connectedness),

- skalowanie (scalability),

- reagowanie (responsiveness),

- dwoistość (duality),

- $\quad$ kolistość (circularity) ${ }^{9}$.

Pierwszą z wymienionych kategorii jest budowanie więzi z interesariuszami, a nie jak dotychczas tworzenie zależności ekonomicznych, które niestety nie zdołały uchronić przed kryzysem. Z tej koncepcji bezpośrednio wynika druga różnica dotycząca skali działań. Dobre praktyki konkretnych firm powinny zostać poszerzone na jak największą skalę. Rozwój technologiczny obliguje przedsiębiorstwa do działań globalnych, szerszych niż

\footnotetext{
${ }^{8} \mathrm{http}: / /$ www.csrinternational.org/about/stages (dostęp: 30 XI 2012).

${ }^{9} \mathrm{~W}$. Visser, op.cit.
} 
lokalne środowisko. Świat mediów społecznościowych zmienia zasady działań firm i co najważniejsze - sposobu komunikacji. Tradycyjne ujęcie w takich przypadkach nie pozwala na sprawne działanie, można nawet powiedzieć, że jesteśmy zobligowani do działania globalnego zdaniem Vissera.

Kolejną cechą różnicująca jest zdolność reagowania i umiejętność podejmowania trudu skorelowanego z rozwiązywaniem kwestii społecznych i środowiskowych na dużą skalę. Takie działania prowadzą przede wszystkim do postrzegania firmy jako transparentnej, a jej przedsięwzięć przejrzystych. Innym aspektem, który sprawia, że można mówić o nowej odpowiedzialności społecznej, jest wspomniana już globalność, jednak w odniesieniu do problemów lokalnych. Nie można zapominać w swoich przedsięwzięciach, że należy działać poprzez pryzmat lokalnych wyzwań, jednocześnie pamiętając, że działa się w świecie, który bardzo się zmienił. Ten postulat przywodzi na myśl zagadnienie glokalizacji, w którym mówi się o potrzebie adaptacji globalnych strategii do możliwości lokalnych wedle popularne zasady: „myśl globalnie, działaj lokalnie”. Ostatnim z elementów jest zagadnienie cyklu zamkniętego. Potrzebujemy modelu, który zamknie cykl produkcji, jednocześnie przyczyniając się do zwiększenia szeroko rozumianego dobra (a nie jak w wypadku tradycyjnego ujęcia - minimalizowania zła). Wayne Visser mówi o budynkach, które na podobieństwo świata przyrody, powinny wytwarzać więcej energii aniżeli ilość, jaką pobierają.

Ciekawym ujęciem jest również porównanie przekształcającego się CSR do nici DNA; nowa odpowiedzialność to nie piramidy, które lekceważą kwestie środowiskowe, to także nie są definicje, które nie zauważają globalnej skali, a jedynie środowisko lokalne oraz ujęcia, które przyjmują zachodnie założenia kulturowe jako jedyne. Nowe ujęcie kładzie nacisk na dwa pojęcia, które wynikają z inspiracji ekologią i problematyką społeczną: „,zrównoważony” i „odpowiedzialny”. To zrównoważony rozwój i odpowiedzialny biznes są jak nić DNA społecznej odpowiedzialności biznesu. Podobnie jak nić DNA jest matrycą dla całego sprawnie funkcjonującego organizmu, tak nić stworzona z odpowiedzialnego biznesu i zrównoważonego rozwoju może być matrycą dla całego CSR. DNA tworzą cztery „zasady azotowe”: adenina, guanina, cytozyna oraz tymina, istotą społecznej odpowiedzialności zaś również będą cztery zasady, jednak dla każdej z oplatającej nici. Zrównoważony rozwój może być traktowany jako wyzwania, wizje, strategie oraz to, do czego się dąży; natomiast odpowiedzialności towarzyszą: rozwiązania, odpowiedzi, zarządzanie i działania. Zdaniem Vissera powinniśmy zapomnieć, że to aspekt ekonomiczny przyświeca zachowaniom biznesowym, najwyższy czas pomyśleć o prawdziwej odpowiedzialności za społeczność, za środowisko, za otaczający nas świat. Czas zapomnieć o wszystkich tradycyjnych definicjach, które za każdym razem rozpoczynały dyskusje od ekonomicznych aspektów. Przyszedł czas na dojrzałą i dorosłą odpowiedzialność ${ }^{10}$. Czas na zawrócenie Titanica, a nie ratowanie go łyżeczką przed utonięciem ${ }^{11}$, do czego sprowadzały się działania tradycyjnego CSR.

\section{ZAKOŃCZENIE}

Jednym z pierwszych wniosków, które nasuwają się po porównaniu tradycyjnego ujęcia CSR z tak zwanym CSR 2.0, to zauważalna zmiana wektora zmian. W XX wieku

\footnotetext{
${ }^{10}$ Por. W. Visser, The Age of Responsibility: CSR 2.0 and the New DNA of Business, Wiley, London 2011.

${ }^{11}$ W. Visser, CSR.2.0, The Evolution...
} 
patrzyliśmy z lokalnej perspektywy na coraz szybciej rozwijający się i w konsekwencji globalny świat. Dzisiaj taki sposób działania wydaje się nie tylko wysoce nieskuteczny, ale nawet szkodliwy. Współcześnie jesteśmy zobligowani do spojrzenia z punktu globalnych przemian, jednak równocześnie bez zapominania o lokalnych wyzwaniach.

Kolejna uwaga dotyczy potrzeby świadomości powstania i w konsekwencji budowania nowych praktyk związanych z CSR. Współcześnie tradycyjne ujęcie działań wynikających z deklaracji i chęci bycia społecznie odpowiedzialnym okazało się mało skuteczne, a odpowiedzialność w rzeczywistości mało odpowiedzialna. Okazuje się, że przyszedł czas na zmiany i jak pisze Wayne Visser: „Umarł CSR! Niech żyje CSR!”12.

\section{LITERATURA}

[1] Komunikat Komisji do Parlamentu Europejskiego, Rady, Europejskiego Komitetu Ekonomiczno-Społecznego i Komitetu Regionów oraz odnowiona strategia UE na lata 2011-2014 dotycząca społecznej odpowiedzialności przedsiębiorstw:

http://eur-lex.europa.eu/LexUriServ/LexUriServ.do?uri=COM:2011:0681:FIN:PL:PDF (dostęp: 15 VIII 2012)

[2] P. Polowczyk, Odpowiedzialność biznesu i podmiotów gospodarczych: definicje, modele, typologia argumentacji, „Zarządzanie zmianami” 2012/1

[3] J. Stecko, Zaufanie a społeczna odpowiedzialność biznesu, „Zeszyty Naukowe Politechniki Rzeszowskiej, Zarządzanie i Marketing” 2012/2

[4] V. Swaen, Corporate social responsibility: do managers and consumers have the same conception of ,,doing good”?, https://gin.confex.com/gin/archives/2002/papers/010140Swaen. pdf (dostęp: 30 X 2012)

[5] W. Visser, The Age of Responsibility: CSR 2.0 and the New DNA of Business, Wiley, London 2011

[6] W. Visser, CSR.2.0. The Evolution and Revolution of Corporate Social Responsibility [w:] M. Pohl, N. Tolhurst, Responsible Business: How to Manage a CSR Strategy Successfully, Wiley, London 2010

[7] http://www.odpowiedzialnafirma.pl/o-csr/iso-26000 (dostep: 10 X 2012)

[8] http://www.csrinternational.org/about/stages (dostęp: 30 XI 2012)

\section{CSR 1.0 VS. CSR 2.0 COMPARISON AND ANALYSIS OF TERMS}

The article deals with the issues of both historical and contemporary possibility of defining CSR. The aim of this paper is to review the definition of corporate social responsibility, which emerged in the twentieth century, and a comparison of the collected material together with the approach which was launched in the twenty-first century. It was also analyzed the development proposed by Wayne Visser who openly speaks about the need for revival of CSR, as previously proposed approach did not come true.

DOI: 10.7862/rz.2012.zim.10

\footnotetext{
${ }^{12}$ Ibidem.
} 